\title{
Influence of welding on aluminium alloy AW6082-T6 strength
}

\author{
Alla Katanina, Oleg Kornev, Aleksandr Shuvalov, and Eugenia Sokolova* \\ Moscow State University of Civil Engineering, Yaroslavskoe shosse, 26, Moscow, 129337, Russia
}

\begin{abstract}
Comparison of welding influence on structural strength of Al$\mathrm{Mg}$-Si alloy (AW6082-T6), supplied with $10 \mathrm{~mm}$ thick sheets, is made. Within the research tension and impact tests of welding joints, made with argon-arc and friction stir welding, were carried out. During the research we observed the following: strength and plasticity decrease for welding joint zones, impact strength increase of weld metal in friction stir welding, welding defects influence on joint strength.
\end{abstract}

\section{Introduction}

Following [1,2] we researched welding influence on short duration loading resistance of aluminium specimens made of semi-finished products of aluminium alloy 6082 based on alloying system Al-Si-Mg.

Industrial aluminium alloys marked the $6 \mathrm{xxx}$ series (Al-Si-Mg alloying system) were included in the new edition of GOST 4784-2019. The alloys of the series are not susceptible to brittle fracture at low temperatures as well as their analogues of Russian marking AV, AD31, AD33, AD35. They are recommended by SP [3] and widely used for medium loaded building structures. Maximum strength of Al-Si-Mg alloys does not exceed $350 \ldots 400 \mathrm{MPa}$. Almost all kinds of light semi-finished products are made from these alloys [4-6].

Having high values of weight and economic efficiency, raw material supply, corrosion resistance, technological effectiveness of making and shaping (profile extrusion at the speed 10 times higher than for other systems), application of heat-strengthened Al-Si-Mg alloys in welded structures is limited to weldability [7]. At the present time simultaneously with industrial technology improvement of argon-arc, plasma arc (PAW) and laser beam welding (LBW) for aluminium alloys the welding joints made with progressive types of solid-state welding [4,5] have reached high efficiency. These include friction stir welding (FSW). According to [8-15] FSW (patented by TWI in 1991) is a new effective method of joining aluminium and its alloys though in [9] it is noted that there is much earlier author's certificate for this type of welding in the USSR.

Energy consumption for FSW is $2.5 \%$ of one consumed by LBM and $10 \%$ of energy for arc welding [9]. According to calculations given in [4] the cost of butt weld per running meter (excluding the equipment and preparatory work cost) for automatic plasma welding of Al-Mg alloy of $5 \mathrm{~mm}$ thickness is 7.8 times higher than the cost for FSW.

* Corresponding author: jane10.08.98@yandex.ru 
Friction stir welding is carried out in a solid state without melting of the base and filler metal due to the plastic flow of welding edges during translational motion of a rotary welding tool along a joint line. In the center of the weld there is the stirred zone (SZ) that coincides approximately with the location of the tool pin during FSW. To the left and to the right sides of the stirred zone metal has thermo-mechanical affected (TMAZ) and heataffected zones (HAZ) [14-16].

However, the processes of FSW have not been studied sufficiently $[15,17,18]$. Thermomechanical affection of FSW may lead to strength loss of aluminium alloy joints down to 0.63 of the base metal strength. Tensile and impact resistance of FSW joints depends not only on welding equipment but also on the sequence of welding and heat treatment operations (Table 1).

Table 1. Influence of FSW technology on butt welds of AD35 alloy of $5 \mathrm{~mm}$ thickness [4]

\begin{tabular}{|c|l|c|c|c|c|c|}
\hline № & Sequence of operations & $\begin{array}{c}\sigma_{u}^{b m}, \\
\mathrm{MPa}\end{array}$ & $\begin{array}{c}\sigma_{u}^{w}, \\
\mathrm{MPa}\end{array}$ & $\sigma_{u}^{w} / \sigma_{u}^{b m}, \%$ & \multicolumn{2}{|c|}{$\mathrm{KCU}, \mathrm{J} / \mathrm{cm}^{2}$} \\
\cline { 5 - 7 } & & & & \\
meld & HAZ \\
\hline 1 & $\begin{array}{l}\text { Quenching + artificial } \\
\text { aging + FSW }\end{array}$ & 314 & 289 & 92 & 14,8 & 12,0 \\
\hline 2 & $\begin{array}{l}\text { Quenching + FSW + } \\
\text { artificial aging }\end{array}$ & 314 & 306 & 97 & 16,2 & 13,5 \\
\hline
\end{tabular}

According to [16] joint efficiency of Al-Mg-Si alloys during friction welding comes to more than $90 \%$ after hot extrusion, $77.22 \%$ after quenching and $62.03 \%$ after both quenching and artificial aging. 6082-T4 lap joint [19] made at $6^{\circ}$ of the welding tool fractured at the ultimate strength $195 \mathrm{MPa}\left(\sigma_{u}^{w} / \sigma_{u}^{b m}=95 \%\right)$. At angle of $7^{\circ}$ the ultimate strength was only $119 \mathrm{MPa}\left(\sigma_{u}^{w} / \sigma_{u}^{b m}=58 \%\right)$. Meanwhile, the core of the welding joint was homogeneous and had no defects.

The study aims to research influence of friction stir welding and mechanized argon-arc welding, when assembling sheet structures at the factory, on tensile and impact resistance of $10 \mathrm{~mm}$ thick 6082 aluminium alloy.

\section{Methods and materials}

Specimens of an industrial alloy, produced as AW6082-T6 according to the international marking, were studied. Material supply included hot-rolled sheet and extrusion strip of 10 $\mathrm{mm}$ thickness, their condition was quenching after heating to the shaping process temperature with subsequent artificial aging. The products were welded test products made with pressure welding (friction welding method) and fusion welding (arc welding method). The specimens, cleaned flush with base metal on both sides and cut from original material (the hot-rolled sheet and the extrusion strip) and across the welds, were provided by Cheboksary Company 'Sespel'. The welding joints made without heat treatment were produced by the company with the subsequent technologies: friction stir welding (FSW) and mechanical multi-pass argon-arc welding with ER 4047 electrode wire. Real chemical composition of the product metal and welds was examined with the emission spectrometry instrument ARL EasySpark. The results are presented in Tables 2 and 3. 
Table 2. Chemical composition of the major alloying elements for AW6082-T6 base metal and welding joints of FSW (percent by mass)

\begin{tabular}{|l|c|c|c|c|c|c|c|c|}
\hline $\begin{array}{l}\text { Points on } \\
\text { the front } \\
\text { side of }\end{array}$ & $\mathrm{Si}$ & $\mathrm{Mg}$ & $\mathrm{Mn}$ & $\mathrm{Cu}$ & $\mathrm{Zn}$ & $\mathrm{Cr} / \mathrm{Ti}$ & $\mathrm{Fe}$ & $\begin{array}{c}\text { Others (for } \\
\text { every } \\
\text { element) }\end{array}$ \\
\hline $\begin{array}{l}\text { rolled } \\
\text { sheet }\end{array}$ & 1.163 & 0.885 & 0.663 & 0.049 & 0.0650 & $0.046 / 0.053$ & 0.298 & $<0.06$ \\
\hline $\begin{array}{l}\text { extrusion } \\
\text { strip }\end{array}$ & 1.154 & 0.787 & 0.676 & 0.015 & 0.010 & $0.003 / 0.008$ & 0.251 & $<0.08$ \\
\hline $\begin{array}{l}\text { base } \\
\text { metal }\end{array}$ & 1.129 & 0.876 & 0.662 & 0.050 & 0.0620 & $0.046 / 0.053$ & 0.291 & $<0.020$ \\
\hline $\begin{array}{l}\text { weld } \\
\text { metal }\end{array}$ & 1.129 & 0.876 & 0.662 & 0.050 & 0.0620 & $0.046 / 0.053$ & 0.291 & $<0.020$ \\
\hline
\end{tabular}

Table 3. Chemical composition of the major alloying elements for AW6082-T6 base metal and welding joints of argon-arc welding (percent by mass)

\begin{tabular}{|l|c|c|c|c|c|c|c|c|}
\hline Composition & $\mathrm{Si}$ & $\mathrm{Mg}$ & $\mathrm{Mn}$ & $\mathrm{Cu}$ & $\mathrm{Zn}$ & $\mathrm{Cr} / \mathrm{Ti}$ & $\mathrm{Fe}$ & $\begin{array}{c}\text { Others } \\
\text { (for } \\
\text { every } \\
\text { element) }\end{array}$ \\
\hline rolled sheet & 1.163 & 0.885 & 0.663 & 0.049 & 0.0650 & $\begin{array}{c}0.046 / \\
0.053\end{array}$ & 0.298 & $<0.06$ \\
\hline base metal & 1.151 & 0.873 & 0.662 & 0.049 & 0.065 & $\begin{array}{c}0.046 / \\
0.049\end{array}$ & 0.304 & $<0.009$ \\
\hline $\begin{array}{l}\text { front side of } \\
\text { the welding } \\
\text { joint }\end{array}$ & 11.787 & 0.019 & 0.016 & 0.05 & 0.006 & - & 0.151 & $<0.015$ \\
\hline $\begin{array}{l}\text { ER 4047 } \\
\text { electrode } \\
\text { wire }\end{array}$ & $\begin{array}{c}11.0 \ldots \\
13.0\end{array}$ & $<0.1$ & $<0.5$ & - & $<0.2$ & - & $<0.80$ & $<0.05$ \\
\hline
\end{tabular}

The confirmation of real chemical composition conformity for product material and base metal of the joints to EN AW-6082 alloy composition (according to GOST 4784-2019 and EN 573-3:2013), and for weld metal to ER 4047 electrode wire composition (according to AWS A5.10) was obtained.

Standard $10 \mathrm{~mm}$ thick specimens for strength and impact testing were made according to requirements of GOST 1497, GOST 6996, GOST 9454. Specimen types undergone a tensile test with strain localization (R12) for each butt joint zone (weld metal - WM, fusion line - FL and heat-affected zone - HAZ for argon-arc welding) are shown in Fig.1.

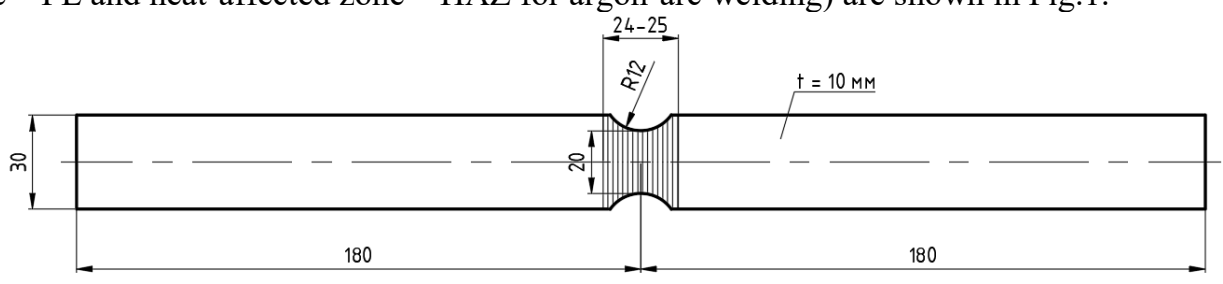

Fig. 1. Specimen for tensile testing with strain localization in weld metal $(\mathrm{R}=12 \mathrm{~mm})$.

To determine impact strength of the material and the welds $55 \times 10 \times 10 \mathrm{~mm}$ size specimens were used with $\mathrm{V}$-notch $(\mathrm{R}=0.5 \mathrm{~mm})$ and $\mathrm{U}$-notch $(\mathrm{R}=1 \mathrm{~mm})$ in different zones (Fig.2 and Fig.3). The disposition of a notch on a specimen was located by welding section 
macrostructure after chemical etching ( $1 \mathrm{~g}$ of sodium hydroxide, $4 \mathrm{~g}$ of potassium permanganate, $100 \mathrm{ml}$ of water).

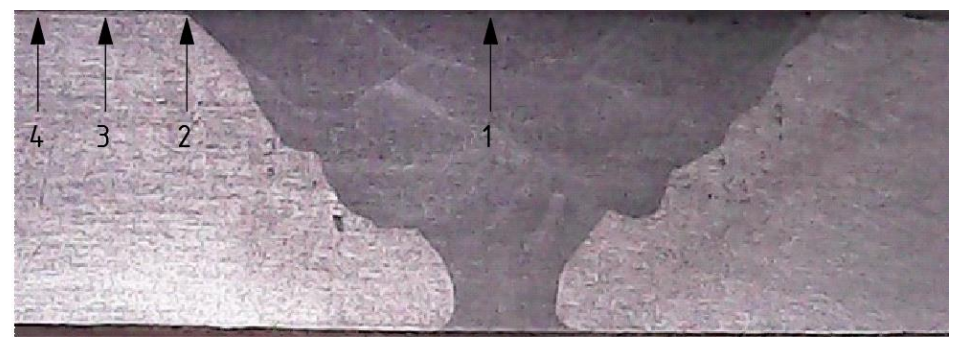

Fig. 2. Specimens for impact test of welding joint made with argon-arc welding. Notch disposition: 1 - WM, 2 - FL, 3 - HAZ, 4 - base metal

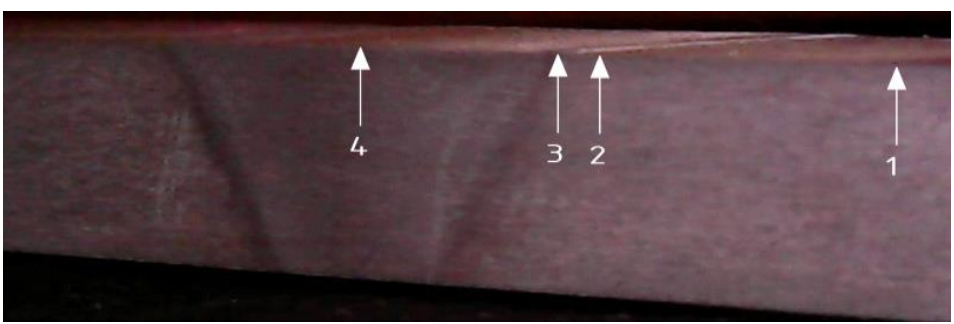

Fig. 3. Specimens for impact test of welding joint made with friction stir welding. Notch disposition: 1 - base metal, 2 - HAZ, 3 - TMAZ, 4 - stirred zone (nugget) [10-15]

Tensile tests were performed in testing machines Instron 8802, Instron 3382, Instron Satec 1000HDX at room temperature. To determine impact strength we used pendulum impact tester Instron 450 MPX SI-1M. Specimens strain under tensile stress were registered with $1 \mathrm{~mm}$ length strain gauges.

Welding joint structure, fracture surface and weld defects were determined visually using the optical microscope (MIN-9 with digital eyepiece camera Bresser MikrOkular Full HD and Digimicro-2.0mpix). To examine particular fracture zones we used the scanning electron microscope Quanta 200 with the built-in energy dispersive spectroscopy system.

\section{Test results and discussion}

Acceptance tensile testing of flat specimens of AW6082-T6 cut from sheet and strip of 10 $\mathrm{mm}$ thickness along rolling and extrusion directions showed that metal working process influences structure material strength and plasticity (Fig. 4). 


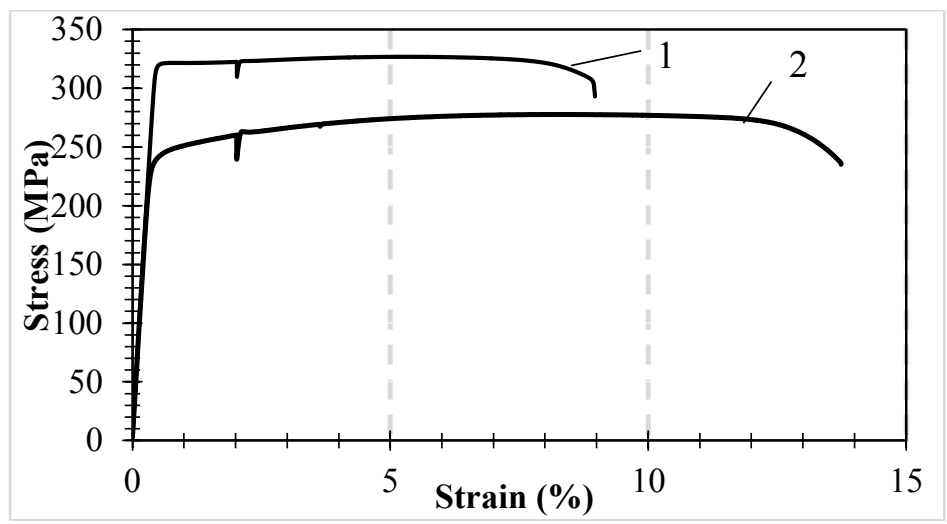

Fig. 4. Tensile resistance of AW6082-T6 base metal of the sheet metal (1) and the extrusion strip (2).

The extrusion strip is inferior to the sheet metal in terms of strength but shows higher plasticity. Yield strength $\sigma_{02}$ of the strip is $24 \%$ less (323.2 and $244.8 \mathrm{MPa}$ respectively) but integral characteristics of plasticity are $33 \%$ higher for relative cross-section reduction $\psi(36.3 \%$ and $27.4 \%), 38 \%$ higher for relative elongation $\delta(18.3 \%$ and $13.3 \%$ respectively) which is caused by grain size decrease in the structure.

Having determined the impact strength $\left(\mathrm{KCV}, \mathrm{KCU}, \mathrm{J} / \mathrm{cm}^{2}\right)$ of specimens with $\mathrm{V}$ - and U-notches made along $10 \mathrm{~mm}$ thickness of the product, it was established that the values for the sheet are lower than for the strip and stay at the same level within the whole temperature range from $-60^{\circ} \mathrm{C}$ to $+20^{\circ} \mathrm{C}$. Average impact strength for AW6082-T6 alloy is $12 \mathrm{~J} / \mathrm{cm}^{2} \mathrm{KCV}$ and $19 \mathrm{~J} / \mathrm{cm}^{2} \mathrm{KCU}$ for the sheet after rolling, quenching and artificial aging and $30 \mathrm{~J} / \mathrm{cm}^{2} \mathrm{KCV}$ and $40 \mathrm{~J} / \mathrm{cm}^{2} \mathrm{KCU}$ for the strip with the same heat treatment procedure.

After the tests in static tension condition rolled and pressed products differed in fracture surface also known as 'orange peel' (Fig. 5).

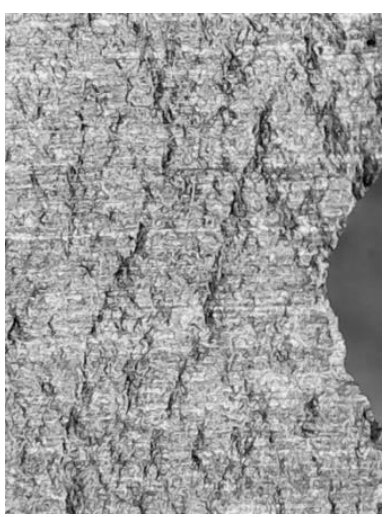

a)

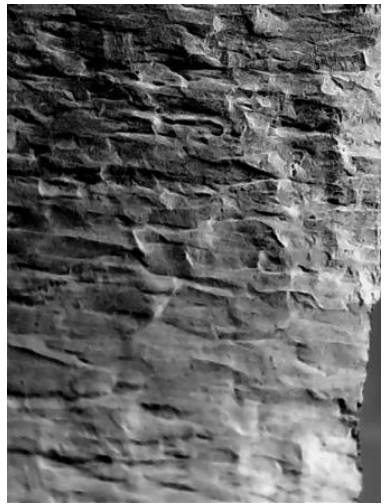

b)

Fig. 5. Macrostructure of the surface: a) for the sheet product with $\psi=27.4 \%, \delta=13.3 \%$, b) for the extrusion strip with $\psi=36.3 \%$ и $\delta=18.3 \%$.

It is known [20-22] that crystalline solid surface reflects inner plastic deformation processes and defines contact interaction which occurs during the pressure welding. Forming of more corrugated surface on the extruded metal confirms greater value of the surface layer deformation in comparison with the one of the sheet surface.

The results of uniaxial tensile testing carried out for specimens with strain localization in weld metal and its boundaries (FL, HAZ) are shown in Table 4. 
Table 4. Influence of welding on strength and plasticity of AW6082-T6 specimens fractured in strain localization zones with $12 \mathrm{~mm}$ radius

\begin{tabular}{|l|c|c|c|c|c|}
\hline \multirow{2}{*}{ Specimen type } & $\begin{array}{c}\text { Welding } \\
\text { method }\end{array}$ & $\begin{array}{c}\text { Elastic } \\
\text { modulus } \\
\mathrm{E}, \mathrm{MPa}\end{array}$ & $\begin{array}{c}\text { Ultimate } \\
\text { strength } \\
\sigma_{u}, \mathrm{MPa}\end{array}$ & $\sigma_{u}^{w} / \sigma_{u}^{b m}$ & $\begin{array}{c}\text { Relative cross- } \\
\text { section } \\
\text { reduction after } \\
\text { fracture } \psi, \%\end{array}$ \\
\hline $\begin{array}{l}\text { Smooth } \\
\text { specimen BM }\end{array}$ & - & 72791 & 330 & - & 27.4 \\
\hline $\begin{array}{l}\text { Localization } \\
\text { in the center } \\
\text { of the weld }\end{array}$ & FSW & 71293 & 308.6 & 0.94 & 19.5 \\
\cline { 2 - 6 } & Argon-arc & 78584 & 248.7 & 0.75 & 9.1 \\
\hline $\begin{array}{l}\text { Localization } \\
\text { in 1 mm } \\
\text { distance from }\end{array}$ & FSW & 82410 & 284 & 0.86 & 10.9 \\
\cline { 2 - 6 } CL/FL & Argon-arc & 81189 & 246.8 & 0.74 & 6.8 \\
\hline $\begin{array}{l}\text { Localization } \\
\text { in 2 mm } \\
\text { distance from }\end{array}$ & $\begin{array}{l}\text { FSW } \\
\text { CL/FL }\end{array}$ & 85791 & 286.3 & 0.87 & 13.5 \\
\cline { 2 - 6 } & Argon-arc & 83155 & 246.9 & 0.75 & 8.7 \\
\hline Note: CL is connection line for FSW, FL is fusion line for argon-arc welding. \\
\hline
\end{tabular}

Ultimate strength of all EN AW6082-T6 specimens made with argon-arc welding and S-Al 4047A electrode wire exceeds minimum acceptable value $(134 \mathrm{MPa})$ for tensile testing of cruciform joints [23]. On the tested joint specimens made with mechanical multilayer and multi-pass argon-arc welding we did not observe hot cracking and the weld strength was $75 \%$ of the one of base metal. It is typical for weld metal to have cast structure with differently oriented layers of large dendrites and porosity (Fig. 6a).

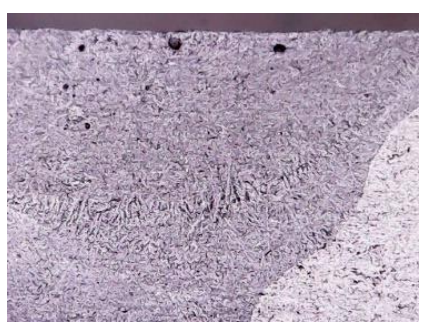

a)

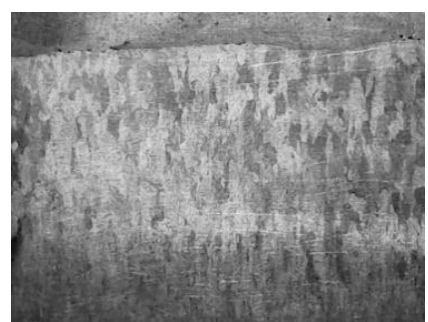

b)

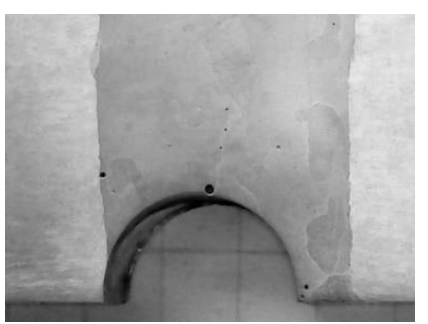

c)

Fig. 6. Macrostructure and porosity of argon-arc welding joints: a) top of the weld section, b) FL and HAZ, c) joint width with strain localization R12.

Advantages of base metal strengthening (T6 mode) disappear in welding joint made with argon-arc welding due to alloy composition change and overheat of HAZ metal (Table 4, Fig. 6b). Strength, plasticity and impact strength decrease of the weld is caused by approximation of alloy chemical composition to the one of a low melt eutectic alloy (Table 3 ), decrease of solid solution fraction in the structure and also grain and second phase particles enlargement (Fig. 6b). Pores increase stress concentration in the notch (Fig. 6c).

Table 5 shows the temperature dependence of impact strength of argon-arc joint specimens with $\mathrm{V}$ - and $\mathrm{U}$-notches made along welding joint zones in comparison with base metal (BM). 
Table 5. Impact strength test results for specimens with notches in different zones of the argonarc welded joint

\begin{tabular}{|c|c|c|c|c|c|c|c|c|c|c|}
\hline \multirow[t]{3}{*}{$\begin{array}{l}\text { Notch } \\
\text { zone }\end{array}$} & \multicolumn{5}{|c|}{$\begin{array}{c}\text { Impact strength KCV at temperature } \\
\left({ }^{\circ} \mathrm{C}\right) \text { of }\end{array}$} & \multicolumn{5}{|c|}{$\begin{array}{l}\text { Impact strength } \mathrm{KCU} \text { at temperature } \\
\left({ }^{\circ} \mathrm{C}\right) \text { of }\end{array}$} \\
\hline & +20 & 0 & -20 & -40 & -60 & +20 & 0 & -20 & -40 & -60 \\
\hline & \multicolumn{5}{|c|}{$\left[\mathrm{J} / \mathrm{cm}^{2}\right]$} & \multicolumn{5}{|c|}{$\left[\mathrm{J} / \mathrm{cm}^{2}\right]$} \\
\hline $\mathrm{BM}$ & 11.3 & 11.8 & 11.9 & 11.9 & 12.5 & 18.3 & 18.6 & 19.4 & 19.8 & 20.7 \\
\hline WM & 12.8 & - & 10.0 & 9.0 & 11.1 & 14.9 & - & 15.6 & 15.6 & 15.7 \\
\hline FL & 32.8 & - & 30.7 & 35.1 & 34.6 & 40.9 & - & 41.6 & 45.3 & 42.6 \\
\hline HAZ & 33.0 & - & 35.2 & 36.9 & 35.7 & 43.2 & - & 42.4 & 45.4 & 45.5 \\
\hline
\end{tabular}

According to the results above, temperature decrease does not lead to impact strength decline. Influence of the notch is more significant, KCU values exceed $\mathrm{KCV}$ values by $7 \ldots 9 \mathrm{~J} / \mathrm{cm}^{2}$ in the whole temperature range. Distribution of impact strength average values for weld zones with the minimum in the weld metal has M-shaped profile. Insignificant increase of impact strength average values was observed close to FL. Lack of sharp decline of toughness indicates lack of cold brittleness of the product in the temperature range from $60^{\circ} \mathrm{C}$ to $+20^{\circ} \mathrm{C}$.

Tests for welding joints made with FSW with strain localization R12 along weld zones showed formation of the weld with homogeneous chemical composition (Table 2). Joints with no defects in different zones of FSW fractured at the stress less than for base metal by $6 . .14 \%$. According to static tensile testing results the center area of the weld, also known as stirred zone [10-15], showed the highest plasticity in the joint $(\psi=19.5 \%)$. However, obtained values of $\psi$ in T6 mode are lower than for the base metal with precipitationhardening structure. It is commonly accepted [15] that FSW joint strength decreases at the end of recrystallization, which takes place in materials with initial strengthened state, due to frictional heating and deformations during stirring process.

According to the results of FSW joint tests, impact strength values are approximately constant in the temperature range from $-60^{\circ} \mathrm{C}$ to $+20^{\circ} \mathrm{C}$ which indicates no cold brittleness. Constant level repeats in all weld zones. However, impact strength value distribution for weld zones differs in maximum value in the center of the weld (Fig. 7).

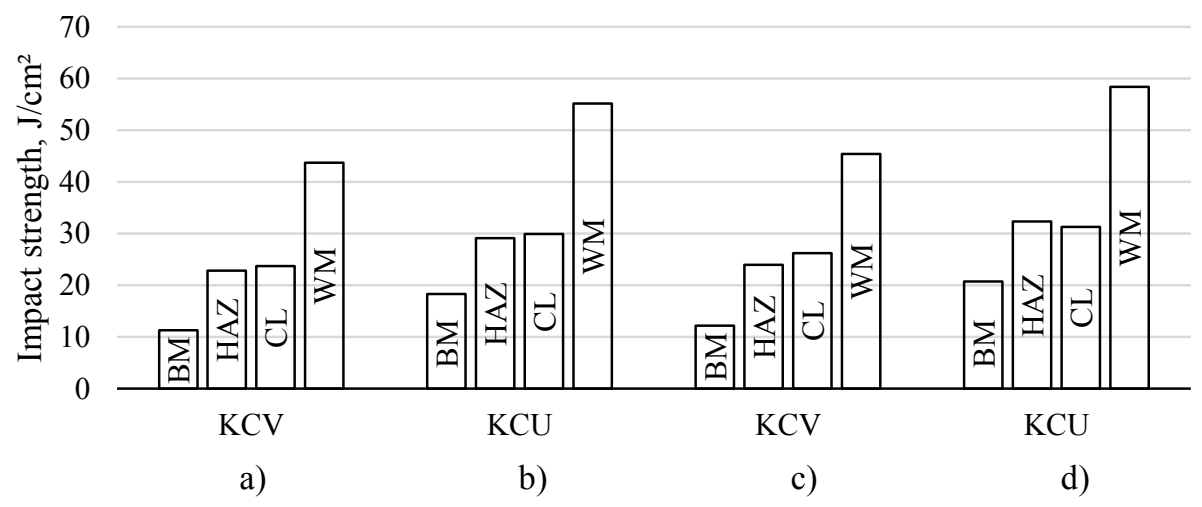

Fig. 7. Impact strength distribution ( $\mathrm{KCV}, \mathrm{KCU})$ for weld zones: a), b) at $+20^{\circ} \mathrm{C}$ test temperature, $\mathrm{c}$ ), d) at $-60^{\circ} \mathrm{C}$ test temperature.

Unlike M-shaped profile of impact strength distribution for argon-arc welded joint zones, average values of impact strength for FSW increases gradually from base metal to the stirred zone. This increase is caused by onion ring structure of the pressure welded joints. In the macrostructure of the weld zone we can see that the sheet product layers, lines 
of which develop with different etching degree, mix and bend (Fig. 8) [24]. It is significant that plexus of cylindrical fibers in the fracture surface of the FSW joint copies the orange peel structure of the extrusion product which indicates the uniform mechanism of formation $[21,22]$.

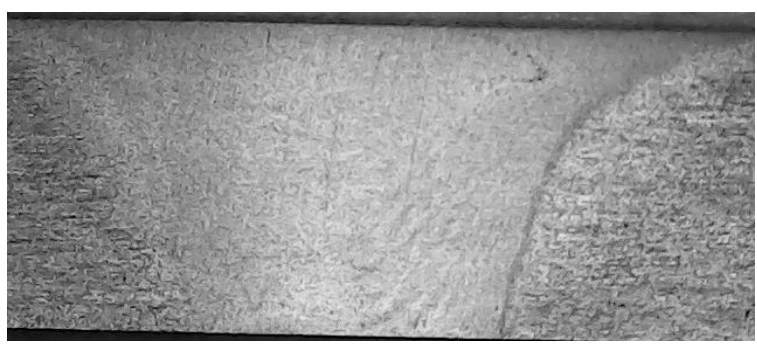

a)

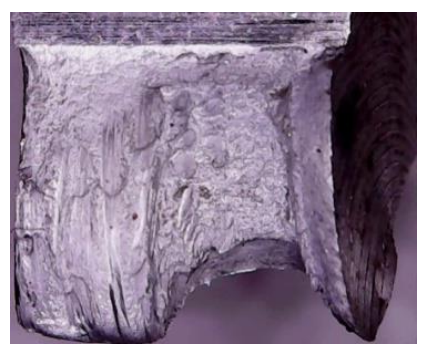

b)

Fig. 8. FSW butt weld: a) onion ring structure along the weld thickness, b) plexus of fibers on the weld fracture surface

According to the results of tensile testing with strain localization shifted from stirred zone to TMAZ, relative cross-section reduction after fracture declined by $44 \%$.

Figure 9 shows welding joint defects related to FSW technology.

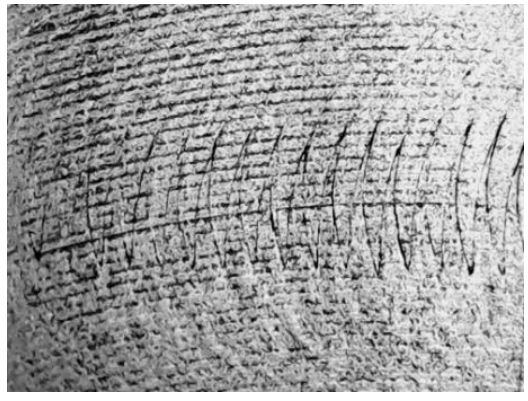

a)

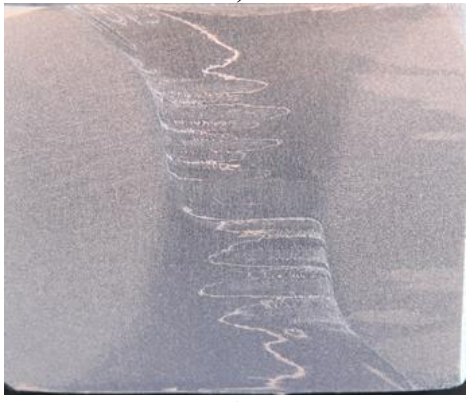

c)

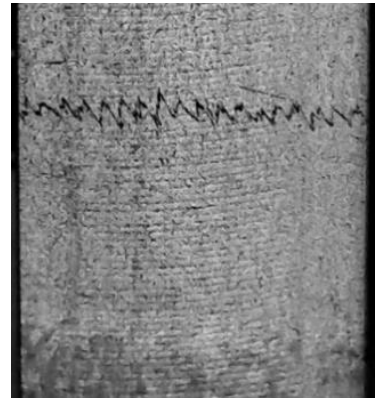

b)

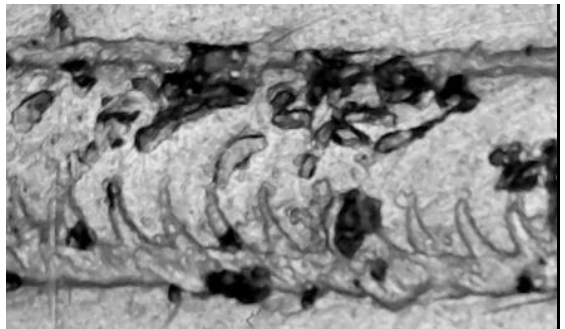

d)

Fig. 9. Defects: a) on the milled surface of weld root, b) on the milled surface on the front side, c) in the weld section according to 'Sespel' data [21], d) defect with metal extrusion in weld root and butt joint relief

Zigzag-shaped microrelief of butt joint was revealed after insignificant mechanical treatment of $1 / 3$ width of root and front side weld surfaces (Fig. 9a). According to [24,25] butt joint relief appears if remnant oxide layer comes to the surface which prevents microprotrusion shear of product end faces. On the studied specimens the relief does not cross weld section in comparison with the results of [18]. In [26] it is shown that material fracture 
with such defect occurs along lines of onion ring structure during tensile testing. However, it is established that joint fracture does not always happen along the highlighted welding defect. Having analyzed tested specimen fracture surface with butt joint relief in the weld root, it was established that this defect did not influence the fracture of FSW joint. The fracture zone was shifted to the side of other defects like unwelded zones on the stirred zone boundary from the retreating side. The fracture started as fast and brittle one along the unwelded zone and ended as ductile at an angle of $45^{\circ}$ in welding joint direction and did not happen along the butt joint relief.

\section{Conclusions}

1. Within the research static and dynamic loading resistance tests were carried out for semifinished products made of AW6082-T6 alloy and their welding joints. It is shown that 10 $\mathrm{mm}$ thick rolled sheet has the strength advantage but plasticity and impact strength are higher for extrusion strip.

2. Technological properties of AW6082-T6 were estimated according to mechanical tests. It was shown that weldability of the alloy is higher for pressure welding than fusion one. The ratio of welding joint strength to base metal strength is $94 \%$ for friction stir welding, 75\% for argon-arc welding. Deformability of extruded semi-finished products is higher than for rolled ones by $33 \ldots .38 \%$ on average.

3. It is established that plasticity determined during tensile testing and impact strength of butt joints made with friction stir welding are higher than the ones made with argon-arc welding.

4. Ductile fracture was determined from the fracture surface structure for all carried-out tests, structure heterogeneity and deformations along weld zones were shown for every welding method.

5. Complex of indicators necessary for computational model of light welded structures is determined.

\section{References}

1. A. Shuvalov, A. Katanina, O. Kornev, M. Kovalev Working capacity of aluminium alloys in structure elements in Proceedings of FORM-2019, 18-21 April 2019, Tashkent, Uzbekistan (2019)

2. A. Shuvalov, A. Katanina, O. Kornev, M. Kovalev Low-cycle fatigue of high processible aluminium alloy flat products from alloyage system $\mathrm{Al}-\mathrm{Mg}-\mathrm{Si}$ in Proceedings of MMSA-2019, 13-15 November 2019, Moscow, Russian Federation (2019)

3. SP 128133302016 Aluminium structures

4. A.M. Drits, V.V. Ovchinnikov Svarka aluminiyevyh splavov. Spravochnik (Moscow: Publishing house 'Ruda i metally') p 440

5. E.N. Kablov Aviatsionnye materialy i tekhnologii S 7-17 (2012)

6. V.V. Ovchinnikov Mashinostroenie i inzhenernoe obrazovanie 3(52) 22-39 (2017)

7. N.A. Belov, E.A. Naumova, T.K. Akopyan Evtekticheskie splavy na osnove alyuminiya: novye sistemy legirovaniya (Moscow: Publishing house 'Ruda i metally') p 256

8. W.M. Thomas, E.D. Nicholas, J.C. Needham, M.G. Murch, P. Templesmith, C.J. Dawes International Patent Application No. PCT/GB92/02203, GB Patent Application No. 9125978.8 (1991) 
9. D.N. Kuritsyn, S.M. Shahrivar, D.S. Moeni Tabatabai Tekhnologicheskaya ehkspertiza proizvodstvennoj tselesoobraznosti primeneniya svarki treniem s peremeshivaniem $v$ spetsialnyh zadachah aehrokosmicheskogo proizvodstva (V sbornike Kosmonavtika: nauka i obrazovanie. Sbornik materialov Vserossijskoj nauchnoj konferentsii. Otvetstvennyj redaktor V.V. Solovev) 83-90

10. A.Ya. Ishchenko, S.V. Podelnikov, A.G. Poklyatskij Avtomaticheskaya svarka 11 3238 (2007)

11. V.N. Mironenko, N.S. Barabohin Deformatsiya i razrushenie materialov 5 37-41 (2008)

12. K. Mroczka, A. Pietras Arch Mater Sci Eng 40(2) 104-109 (2008)

13. A. El-Danaf Ehab, M. El-Rayes Magdy Materials and Design v.46 561-572 (2013)

14. A. Naumov, E. Rylkov, F. Isupov, A. Rudskoy, I. Morozova, V. Michailov, A. Obrosov Materials v. 12.24 p. 4211 (2019)

15. V.V. Ovchinnikov, A.M. Drits Naukoemkie tekhnologii v mashinostroenii 3(93) 4-11 (2019)

16. C. Yang, D.R. Ni, P. Xue, B.L. Xiao, W. Wang, K.S. Wang, Z.Y. Ma Materials Characterization v. 145 20-28 (2018)

17. M.M. Rebrin Sotsialno-ehkonomicheskie i tekhnicheskie sistemy: issledovanie, proektirovanie, optimizatsiya 1(84) 76-84 (2020)

18. V.A. Bakshaev, P.A. Vasilev Tsvetnye metally 1(853) 75-80 (2014)

19. S. Yu. Ivanov, O.V. Panchenko, V.G. Michailov Metallovedenie i termicheskaya obrabotka metallov 6(756) 53-58 (2018)

20. E.A. Alferova, D.V. Lychagin Zhurnal tekhnicheskoj fiziki v.88 4 555-560 (2018)

21. N.A. Mahutova, Yu.G. Matvienko, A.N. Romanova Problemy prochnosti, tekhnogennoj bezopasnosti $i$ konstruktsionnogo materialovedeniya (Moscow: Publishing house 'LENAND') p 720

22. M.A. Shtremel Razrushenie. V 2 knigah. Kn.1 Razrushenie materiala p 670 Kn.2 Razrushenie struktur p 976 (Moscow: Publishing house MISiS)

23. GOST R 573522016 Building aluminium structures. General specifications

24. GOST R 571252016 Aluminium alloy extruded products. Terms and definitions of defects

25. A.A. Naumov, M.A. Ozhegov, R.I. Smelianskii, A. Alali Alkhalaf, P.Y. Polyakov Materials Science. Power Engineering, v. 26 88-102 (2020)

26. O.V. Sizova, A.V. Kolubaev, E.A. Kolubaev, A.A. Zaikina i dr. Obrabotka metallov (tekhnologii, oborudovanie, instrumenty) 4(77) 19-29 (2017)

All tests were carried out using research equipment of The Head Regional Shared Research Facilities of the Moscow State University of Civil Engineering. 